\title{
Detoxification of chromium (VI) in coastal water using lignocellulosic agricultural waste
}

\author{
Kishore K Krishnani ${ }^{1 *}$, V Parimala ${ }^{2}$ and Xiaoguang Meng $^{1}$ \\ ${ }^{1}$ Centre for Environmental Engineering, Stevens Institute of Technology, Hoboken, 07030, NJ, USA \\ ${ }^{2}$ Central Institute of Brackishwater Aquaculture, Santhome High Road, R.A.Puram, Chennai, 600028, India
}

\begin{abstract}
Development of new economically feasible eco-friendly products from natural plants/agricultural wastes for removal of pollutants from coastal aquaculture systems is the objective of our continued research. In the present study, attempts have been made to harness lignocellulosic agricultural waste material (bagasse) for the removal of chromium (VI) from highly saline coastal water used for aquacultural practices using brackish water. Five different products prepared from bagasse were evaluated for the detoxification of $\mathrm{Cr}(\mathrm{VI})$ from high saline coastal water. The maximum removal capacity for $\mathrm{Cr}$ (VI) was found for the material charred with sulphuric acid. Dried bagasse powder was the second most effective product. These substrates are efficient for $\mathrm{Cr}$ removal from coastal water owing to their very low cost.
\end{abstract}

Keywords: phytoremediation, reduction, chromium, bagasse, coastal waters

\section{Introduction}

The successful growth, propagation and harvest of aquatic animals, whether freshwater or marine, are heavily dependent upon the quality of the surrounding water. Coastal water receive a heavy influx of sewage, industrial effluents, domestic and agricultural waste which consists of varying hazardous chemical and causing deleterious effects on fish and other aquatic organism. Heavy metals are among the conservative pollutants that are not subject to bacterial attack or other breakdown and are permanent additions to the marine environment (El-Nady and Atta, 1996). The primary sources of heavy metals pollution in coastal lagoons are input from rivers, sediments and atmosphere, which can affect aquaculture profitability in certain areas. In recent years, chromium concentrations have been increasing in coastal waters through the electroplating industry, metal finishing, leather tanning and chrome preparation. In the United States, it is the second most common inorganic contaminant in waters, after lead (Wielinga et al., 2001). However, Cr is necessary for normal life processes; it can be toxic to organisms at elevated concentrations. Free metal ionic activity in seawater is a function of metal toxicity, rather than the total concentration of the metal (Viarengo, 1989). Chromium usually exists in both trivalent and hexavalent oxidation states in soils and aqueous systems. The hexavalent form is of particular concern because of its great toxicity resulting from its powerful oxidation properties. The $\mathrm{Cr}$ (VI) is a U.S.EPA classified group A carcinogen based on its chronic effects (Nkhalambayausi-Chirwa and Wang, 2001). This has adverse impact on aquatic species as it accumulates in fish tissues and causes reduction in fish production at high concentrations (Cutter, 1991; Krishnani et al., 2003). The trivalent form of chromium, namely $\mathrm{Cr}$ (III), on the other hand, is about 1000 times less toxic than $\mathrm{Cr}(\mathrm{VI})$. Furthermore, it has a limited hydroxide

* To whom all correspondence should be addressed.

T. 2012168993; fax: 2012168303; e-mail: bioremediationk@yahoo.co.in Received 19 April 2004; accepted in revised form 31 July 2004. solubility making it relatively immobile and less available for biological uptake. As a result, $\mathrm{Cr}$ (VI) toxicity could be reduced and then become less bio-available when reduced to $\mathrm{Cr}$ (III).

Among available conventional processes used to remove hexavalent $\mathrm{Cr}$, the most commonly used are precipitation as chromium hydroxide or ion exchange using macroporous resins (Jianlong et al. 2000). However, these methods suffer from some disadvantages due to their relatively high operational costs and cannot be recommended for $\mathrm{Cr}$ removal from coastal waters. Conversely, in recent years, a promising alternative method for removal of $\mathrm{Cr}(\mathrm{VI})$ uses the sorption by lignocellulosic solid wastes such as sugar- beet pulp (Reddad et al. 2003), wheat bran (Dupond and Guillon, 2003) and saw-dust (Raji and Anirudhan, 1998). Sugarcane bagasse is a highly fibrous lignocellulosic material, which is the residue remaining after sugar cane has been pressed to remove sucrose. Sugar-cane mills produce more bagasse than can be utilised as a fuel source for sugar processing; few commercial uses for the excess bagasse have been developed and its accumulation presents a waste problem for the sugar industry. One potential use of bagasse is as a feedstuff for shrimps (Freeman et al. 1992). However, reports on its use for the detoxification of $\mathrm{Cr}$ (VI) from high saline coastal water are not available. This study reports the use of five different products prepared from bagasse for detoxification of $\mathrm{Cr}$ (VI) in high saline coastal waters under laboratory conditions.

\section{Materials and methods}

\section{Preparation of bagasse products}

Five different kinds of materials were prepared from bagasse:

- Raw bagasse filaments (BRF)

- Dried bagasse filaments (BDF): Raw material was thoroughly washed with water and then dried in sun light

- Dried bagasse powder (BOP): Material dried in sunlight was dried in an oven at $75^{\circ} \mathrm{C}$ for $6 \mathrm{~h}$ and then powdered.

Charred bagasse powder (BCP): Dried material was charred at $250^{\circ} \mathrm{C}$ in a muffle furnace and then powdered. 
- Bagasse charred with sulphuric acid(BSP): Dried material was charred with concentrated sulphuric acid for $24 \mathrm{~h}$. After complete charring, charred materials were thoroughly washed with water to remove sulphuric acid, dried at $100^{\circ} \mathrm{C}$ and then powdered.

\section{Experimental and analytical procedures}

Standard stock solution was prepared from potassium dichromate. For each experimental run, a solution of $\mathrm{Cr}$ metal ion was added to 1 l of coastal water (salinity $35 \pm 1 \mathrm{~g} / \ell$ ) in a glass jar in order to obtain a known concentration of the metal. The resulting solution was treated with five different products of bagasse at concentrations of 3, 6 and $10 \mathrm{~g} / \ell$ with a separate set of control. In addition, water samples were analysed for $\mathrm{Cr}$ concentrations at daily intervals for a period of $6 \mathrm{~d}$. At the end of the experiment, water samples were collected from all the treatments and other water quality parameters such as pH, salinity, alkalinity, ammonia, nitrite, phosphate and total bacterial counts were analysed by standard methods [Strickland and Parson, 1972; Standard Methods, 1989]. Hexavalent Cr in coastal water was determined spectrophotometrically [Standard Methods, 1989] by measurement of the intense red-violet complex formed by reaction of $\mathrm{Cr}$ (VI) with 1,5-diphenyl carbazide in an acidic medium. A Hitachi UV-Visible spectrophotometer was used to obtain measurements of the chromophore complex at its absorbance maximum of $540 \mathrm{~nm}$.

\section{Statistical analysis}

The data were statistically analysed using 5 (duration) x 5 (materials) factorial completely randomised design with two replications for each dose. Duncan's multiple range test was applied to identify significant differences between main effects and interaction effects. M-STATC statistical software was employed to perform statistical analyses.

\section{Results and discussion}

\section{Determination of effective bagasse product and dose for detoxification of $\mathrm{Cr}(\mathrm{VI})$}

The effect of five different products of bagasse at the dose of $3 \mathrm{~g} / \ell$ on the removal of initial $\mathrm{Cr}(\mathrm{VI})$ concentration of $8.126 \mathrm{mg} / \ell$ is presented in Fig.1. This shows that bagasse charred with sulphuric acid (BSP) is most effective in detoxifying $\mathrm{Cr}(\mathrm{VI})$ as this product removed initial $\mathrm{Cr}(\mathrm{VI})$ concentration of $8.126 \mathrm{mg} / \ell$ within $24 \mathrm{~h}$, whereas, in the treatments with charred bagasse powder (BCP), dried bagasse powder(BOP), raw bagasse filaments (BRF) and dried bagasse filaments (BDF), per cent $\mathrm{Cr}(\mathrm{VI})$ removal was $12.6 \%$, $14.6 \%, 8.27 \%$ and $11.3 \%$ in $24 \mathrm{~h}$ respectively. There was a further decline in Cr concentrations and after $48 \mathrm{~h}$, per cent $\mathrm{Cr}$ (VI) removal was $22.8 \%, 22.3 \%, 13.9 \%$ and $11.9 \%$ in $48 \mathrm{~h}, 34.3 \%$, $22.4 \%, 14.9 \%$ and $12.6 \%$ in $72 \mathrm{~h}$ and 38.5\%, 22.6\%, 15.1\% and $13.4 \%$ in $96 \mathrm{~h}$ respectively. Bagasse filaments dried in sun light (DBF) were least effective.

The effect of five different products of bagasse at a concentration of $6 \mathrm{~g} / \ell$ on $8.126 \mathrm{mg} / \ell \mathrm{Cr}(\mathrm{VI})$ is presented in Fig. 2. This shows that BCP, BOP, BRF and BDF decreased initial Cr concentration of $8.126 \mathrm{mg} / \ell$ to the extent of $16.3 \%, 19.5 \%, 10.6 \%$ and $9.33 \%$ in $24 \mathrm{~h}$ and $31.8 \%, 27.9 \%, 16.1 \%$ and $10.8 \%$ in $48 \mathrm{~h}$ and $40.3 \%, 37.9 \%$, $17.4 \%$ and $11.1 \%$ in $72 \mathrm{~h}$ respectively. There was a further decline and after $96 \mathrm{~h}$, the per cent $\mathrm{Cr}$ removal was 57.9\%, 47.8\%, 18.8\% and $12 \%$.

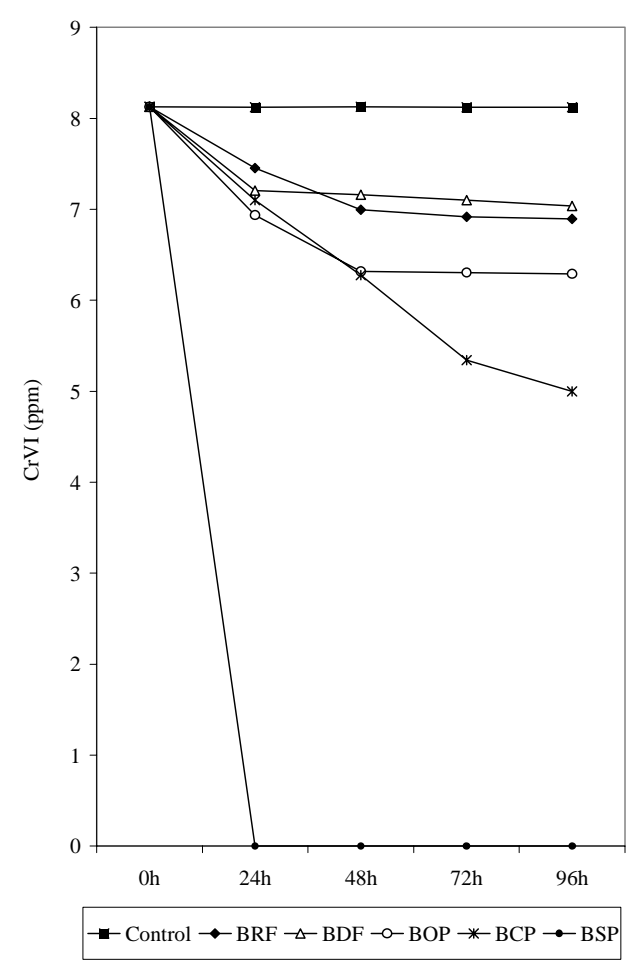

Figure 1

Effect of bagasse products @ $3 \mathrm{~g} / \ell$ on chromium(VI) removal

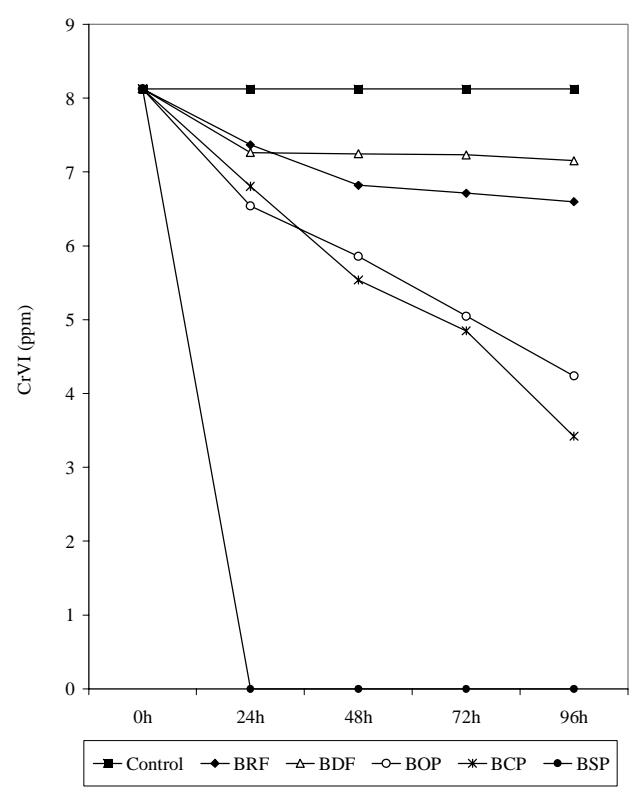

Figure 2

Effect of bagasse products @ 6g/l on chromium(VI) removal

The effect of five different products of bagasse at the concentration of $10 \mathrm{~g} / \ell$ on $8.126 \mathrm{mg} / \ell \mathrm{Cr}$ shows (Fig.3) that BOP, BCP, BRF and BDF, decreased $\mathrm{Cr}$ to the extent of $36.2 \%, 19.7 \%, 11.6 \%$ and $17 \%$ in $24 \mathrm{~h}$ and $61.4 \%, 38.7 \%, 25.4 \%$ and $20.2 \%$ in $48 \mathrm{~h}$ and $85.2 \%$, $62.3 \%, 34.6 \%$ and $20.6 \%$ in $72 \mathrm{~h}$ respectively. There was a further decline and after $96 \mathrm{~h}$, the per cent $\mathrm{Cr}$ (VI) removal was $96.1 \%$, $79.7 \%, 43.6 \%$ and $21.3 \%$. 


\begin{tabular}{|c|c|c|c|c|}
\hline \multicolumn{5}{|c|}{$\begin{array}{c}\text { TABLE1 } \\
\text { Comparison of efficacies of bagasse products for } \\
\text { the removal of } \begin{array}{c}\text { hexavalent chromium from coasta } \\
\text { waters }\end{array}\end{array}$} \\
\hline \multicolumn{2}{|l|}{ Materials } & $3 \mathrm{~g} / \mathrm{l}$ & $6 \mathrm{~g} / \mathrm{l}$ & $10 \mathrm{~g} / \mathrm{l}$ \\
\hline $\begin{array}{l}\text { BRF } \\
\text { BDF } \\
\text { BOP } \\
\text { BCP } \\
\text { BSP }\end{array}$ & \multicolumn{2}{|c|}{$\begin{array}{l}7.278^{\mathrm{B}} \\
7.326^{\mathrm{A}} \\
6.795^{\mathrm{C}} \\
6.368^{\mathrm{D}} \\
1.625^{\mathrm{E}}\end{array}$} & $\begin{array}{l}7.125^{\mathrm{B}} \\
7.402^{\mathrm{A}} \\
5.962^{\mathrm{C}} \\
5.747^{\mathrm{D}} \\
1.625^{\mathrm{E}}\end{array}$ & $\begin{array}{l}6.255^{\mathrm{B}} \\
6.840^{\mathrm{A}} \\
3.595^{\mathrm{D}} \\
4.868^{\mathrm{C}} \\
1.625^{\mathrm{E}}\end{array}$ \\
\hline \multirow[t]{2}{*}{ Materials } & \multirow[t]{2}{*}{ Hours } & \multicolumn{3}{|c|}{ Initial Concentration 8.126 } \\
\hline & & $3 \mathrm{~g} / \mathrm{l}$ & $6 \mathrm{~g} / \mathrm{l}$ & $10 \mathrm{~g} / \mathrm{l}$ \\
\hline $\mathrm{BRF}$ & $\begin{array}{l}24 \\
48 \\
72 \\
96\end{array}$ & $\begin{array}{l}7.454^{\mathrm{B}} \\
6.996^{\mathrm{G}} \\
6.918^{\mathrm{H}} \\
6.869^{\mathrm{H}}\end{array}$ & $\begin{array}{l}7.368^{\mathrm{B}} \\
6.820^{\mathrm{E}} \\
6.712^{\mathrm{F}} \\
6.598^{\mathrm{G}}\end{array}$ & $\begin{array}{l}7.186^{\mathrm{B}} \\
6.064^{\mathrm{G}} \\
5.315^{\mathrm{H}} \\
4.582^{\mathrm{K}}\end{array}$ \\
\hline $\mathrm{BDF}$ & $\begin{array}{l}24 \\
48 \\
72 \\
96\end{array}$ & $\begin{array}{l}7.206^{\mathrm{C}} \\
7.162^{\mathrm{D}} \\
7.098^{\mathrm{E}} \\
7.038^{\mathrm{F}}\end{array}$ & $\begin{array}{l}7.262^{\mathrm{C}} \\
7.245^{\mathrm{C}} \\
7.227^{\mathrm{D}} \\
7.152^{\mathrm{H}}\end{array}$ & $\begin{array}{c}6.742^{\mathrm{C}} \\
6.486^{\mathrm{DF}} \\
6.452^{\mathrm{EF}} \\
6.396^{\mathrm{F}}\end{array}$ \\
\hline BOP & $\begin{array}{l}24 \\
48 \\
72 \\
96\end{array}$ & $\begin{array}{l}6.936^{\mathrm{H}} \\
6.316^{\mathrm{I}} \\
6.306^{\mathrm{I}} \\
6.290^{\mathrm{I}}\end{array}$ & $\begin{array}{l}6.540^{\mathrm{I}} \\
5.856^{\mathrm{K}} \\
5.048^{\mathrm{M}} \\
4.240^{\mathrm{E}}\end{array}$ & $\begin{array}{l}5.184^{\mathrm{I}} \\
3.140^{\mathrm{L}} \\
1.204^{\mathrm{O}} \\
0.320^{\mathrm{P}}\end{array}$ \\
\hline $\mathrm{BCP}$ & $\begin{array}{l}24 \\
48 \\
72 \\
96\end{array}$ & $\begin{array}{l}7.100^{\mathrm{E}} \\
6.274^{\mathrm{I}} \\
5.341^{\mathrm{J}} \\
5.000^{\mathrm{K}}\end{array}$ & $\begin{array}{l}6.804^{\mathrm{J}} \\
5.538^{\mathrm{J}} \\
4.847^{\mathrm{L}} \\
3.420^{\mathrm{N}}\end{array}$ & $\begin{array}{l}6.524^{\mathrm{D}} \\
4.980^{\mathrm{J}} \\
3.062^{\mathrm{M}} \\
1.646^{\mathrm{N}}\end{array}$ \\
\hline BSP & $\begin{array}{l}24 \\
48 \\
72 \\
96\end{array}$ & $\begin{array}{l}0.0001^{\mathrm{L}} \\
0.0001^{\mathrm{L}} \\
0.0001^{\mathrm{L}} \\
0.0001^{\mathrm{L}}\end{array}$ & $\begin{array}{l}0.0001^{\mathrm{O}} \\
0.0001^{\mathrm{O}} \\
0.0001^{\mathrm{O}} \\
0.0001^{\mathrm{O}}\end{array}$ & $\begin{array}{l}0.0001^{\mathrm{Q}} \\
0.0001^{\mathrm{Q}} \\
0.0001^{\mathrm{Q}} \\
0.0001^{\mathrm{Q}}\end{array}$ \\
\hline $\begin{array}{l}\text { Means in th } \\
\text { significantl }\end{array}$ & $\begin{array}{l}\text { vertic } \\
\text { differ }\end{array}$ & $\begin{array}{l}\text { ow with } \\
\text { pd”0.05) }\end{array}$ & erent supers & ts are \\
\hline
\end{tabular}

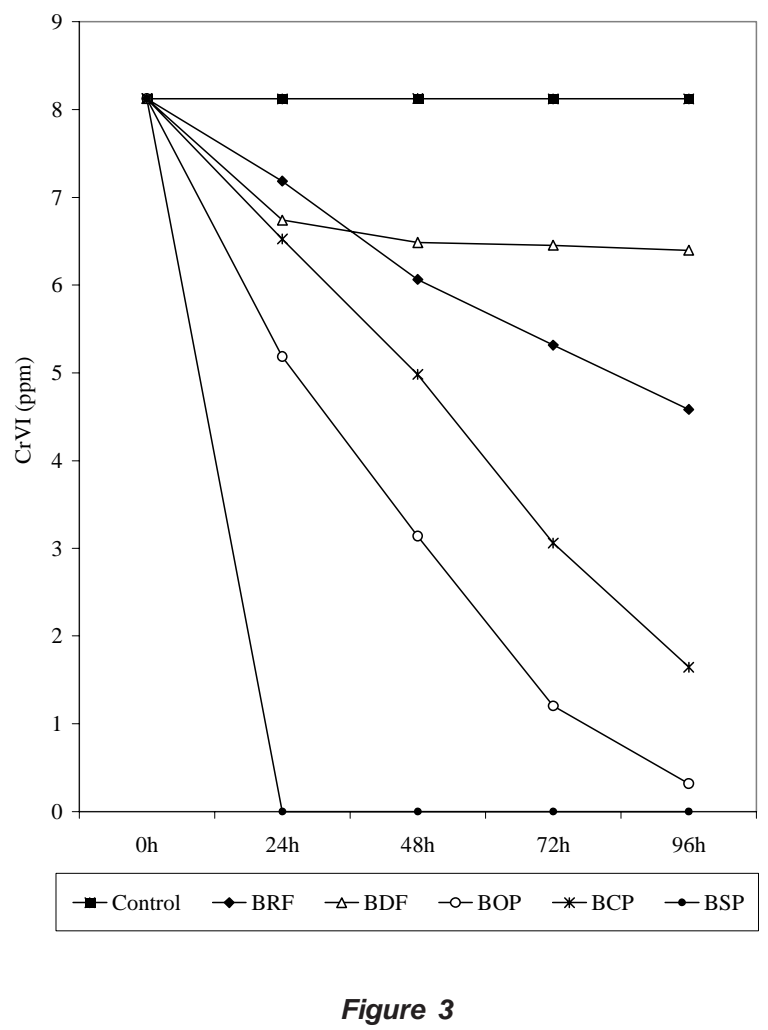

Effect of bagasse products @ 10 g/l on chromium(VI) removal

\section{Effect of bagasse materials on other water quality parameters}

During the course of experiment, other water quality parameters such as salinity, nitrite and ammonia did not show many changes with treatments with BRF, BDF, BOP, BCP and BSP throughout the course of the experiment and they ranged from 34 to $36 \mathrm{~g} / \ell, 0.002$ to $0.02 \mathrm{mg} / \ell$ and 0.029 to $0.329 \mathrm{mg} / \ell$ respectively. Effect of bagasse materials on $\mathrm{pH}$ and phosphates is presented in Fig. 4. This shows that there were not many changes in $\mathrm{pH}$ with the treatment with $\mathrm{BRF}, \mathrm{BDF}, \mathrm{BOP}$ and BCP at 3 to $10 \mathrm{~g} / \ell$ and it ranged from 8.01 to 7.42, whereas BSP at 3, 6 and $10 \mathrm{~g} / \ell$ decreased the $\mathrm{pH}$ from 8.01 to $1.8,1.66$ and 1.45 respectively. From this figure, it is evident that $\mathrm{BRF}, \mathrm{BDF}, \mathrm{BOP}, \mathrm{BCP}$ and $\mathrm{BSP}$ at $3 \mathrm{~g} / \ell$ increased phosphate from $0.032 \mathrm{mg} / \ell$ to $0.118,0.049,0.081,0.041$ and $0.067 \mathrm{mg} / \ell$. Phosphate levels were $0.254,0.051,0.198,0.15$ and $0.131 \mathrm{mg} / \ell$ in the treatments with these materials at $6 \mathrm{~g} / \ell$ and they were $0.398,0.067$, $0.21,0.225$ and $0.201 \mathrm{mg} / \ell$ with the dose of $10 \mathrm{~g} / \ell$ respectively. Highest increase in total plate counts (TPC) was observed with BRF followed by BCP and BOP in alkaline medium, whereas in the case of BSP, TPC decreased in the acidic medium (Fig. 5).

Previous studies (Gerente et al., 2000; Reddad et al., 2002) have revealed that the lignocellulosic substrate is constituted by lignin and cellulose as its major constituents. Lignins bear functional groups such as alcohol, ketones and carboxylic groups that can be involved in complexation reactions with metallic cations. The removal of $\mathrm{Cr}(\mathrm{III})$ and $\mathrm{Cr}(\mathrm{VI})$ from aqueous solutions using sugar-beet pulp as a biosorbent substrate was performed by Reddad et al. (2003) under various experimental conditions and they found that $\mathrm{Cr}(\mathrm{VI})$ removal was largely involved in a reduction mechanism with the appearance of $\mathrm{Cr}(\mathrm{III})$ ions in the solution and the carboxylic groups of the biosorbent is the main reduction sites of $\mathrm{Cr}(\mathrm{VI})$ species. They also found that $\mathrm{Cr}$ (III) ions are adsorbed onto the biosorbent by ion- 


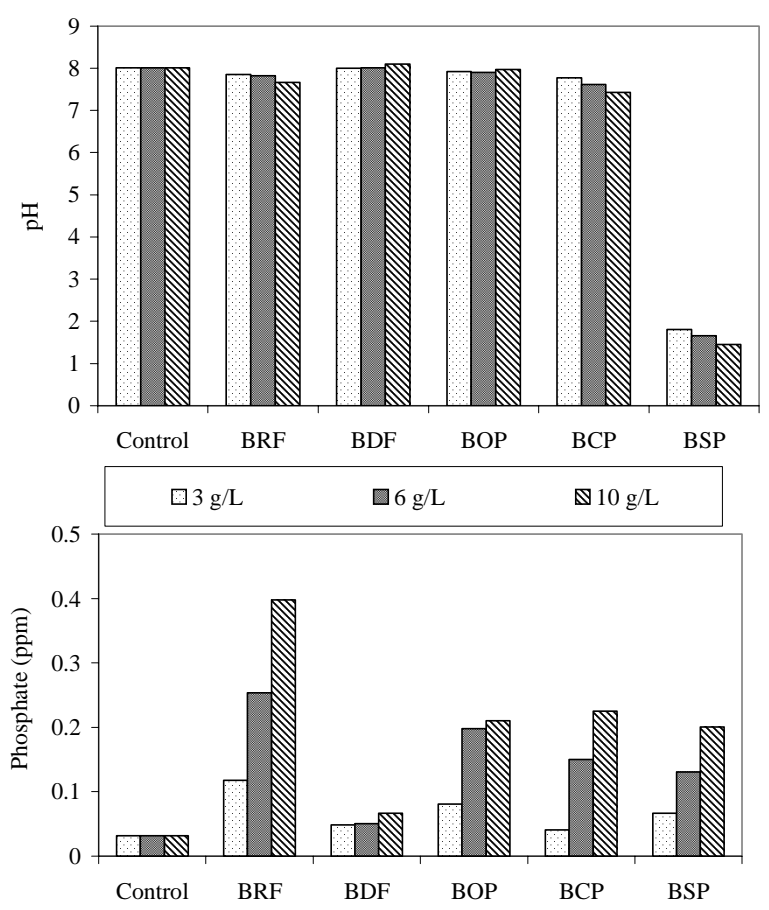

Figure 4

Effect of bagasse products on $\mathrm{pH}$ and phosphate in coastal water

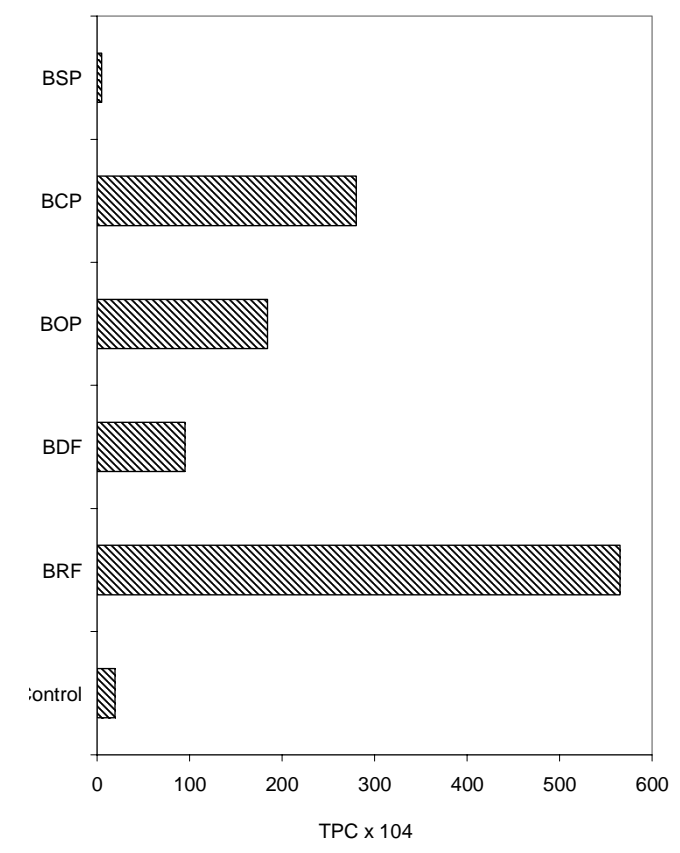

Figure 5

Total plate counts in coastal water treated with bagasse products

exchange mechanism with $\mathrm{Ca}^{2+}$ cations neutralizing the carboxyl groups of the material. The influence of solution $\mathrm{pH}$ greatly affected the adsorption efficiency of $\mathrm{Cr}(\mathrm{VI})$ and the optimum removal resulting from the reduction mechanism was achieved at acidic $\mathrm{pH}$ values (Reddad et al., 2003).

In the present study also, bagasse charred with sulphuric acid (BSP) has been found to be most effective for the detoxification of
$\mathrm{Cr}(\mathrm{VI})$ in the acidic medium, which can be attributed to the reduction of $\mathrm{Cr}(\mathrm{VI})$ into $\mathrm{Cr}(\mathrm{III})$, whereas the removal of $\mathrm{Cr}(\mathrm{VI})$ in the treatments with other bagasse products in alkaline medium may be due to the reduction by increase in native microbial community. Oliver et al. (2003) have conducted a study to assess the potential for immobilising $\mathrm{Cr}$ (VI) using a native microbial community by reducing soluble $\mathrm{Cr}(\mathrm{VI})$ to insoluble $\mathrm{Cr}$ (III) under conditions similar to those in the vadose zone, and to evaluate the potential for enhancing biological $\mathrm{Cr}(\mathrm{VI})$ reduction through nutrient addition, and they have found that native microbial communities in subsurface sediments with no prior $\mathrm{Cr}(\mathrm{VI})$ exposure were shown to be capable of $\mathrm{Cr}(\mathrm{VI})$ reduction. In both the batch and column experiments conducted by Oliver et al. (2003), Cr(VI) reduction and loss from the aqueous phase were enhanced by adding high levels of both nitrate $\left(\mathrm{NO}_{3}\right.$ ) and organic $\mathrm{C}$ (molasses).

\section{Conclusion}

The present study showed that bagasse can be used for the effective removal of $\mathrm{Cr}$ (VI) from coastal waters. The removal of this carcinogenic toxicant was found to depend on materials, dosage and time. Bagasse charred with sulphuric acid(BSP), oven-dried bagasse powder (BOP) and charred bagasse powders (BCP) at 3 to $10 \mathrm{~g} / \ell$ are effective in decreasing $\mathrm{Cr}(\mathrm{VI})$ level within 24 to $96 \mathrm{~h}$. Statistical data shows that amount of $\mathrm{Cr}$ (VI) removal by BRF and BDF at $3 \mathrm{~g} / \ell$ in $72 \mathrm{~h}$ can be achieved using BOP and BCP at $3 \mathrm{~g} / \ell$ in $24 \mathrm{~h}$ respectively. Hence, from this study, it may be concluded that ovendried bagasse powder(OBP) and charred bagasse powder(BCP) are effective products for the detoxification of $\mathrm{Cr}(\mathrm{VI})$ and there was no significant effect of these products on any of the other water quality parameters. Furthermore, bagasse is a biodegradable substrate, which harbours higher periphytic biomass than non-degradable ones. This could be because biodegradable substrates provide a better surface structure for periphytic species to attach to or they may leach nutrients beneficial for the growth of periphyton, which has more than one role in aquaculture. It improves fish/shrimp production and water quality, thus enhancing the efficiency of aquaculture systems. The very low cost of this lignocellulosic material is a real advantage that renders it a suitable alternative for the detoxification of $\mathrm{Cr}(\mathrm{VI})$ and successful studies on this material could be beneficial for the treatment of coastal water being used for aquaculture practices.

\section{Acknowledgements}

Department of Biotechnology, Ministry of Science and Technology, Government of India is gratefully acknowledged for awarding Biotechnology overseas fellowship to Dr KK Krishnani. Authors are thankful to Dr Mathew Abraham, Director, and Dr P Ravichandran, Principal Scientist, CIBA, Chennai for their encouragements.

\section{References}

CUTTER GA (1991) Trace elements in estuarine and coastal waters. Rev. Geophys. (Supplement, Contrib-Oceanog.) 639 pp.

DUPOND L and GUILLON E (2003) Removal of hexavalent chromium with a lignocellulosic substrate extracted from wheat bran. Environ. Sci. Technol. 37 4235-4241.

EL-NADY FE and ATTA MM (1996) Toxicity and bioaccumulation of heavy metals to some marine biota from the Egyptian coastal waters. J. Environ. Sci. Health A-31 (7) 1529-1545.

FREEMAN DW, DUERR EO and LEBER KENNETH M (1992) Use of bagasse as a feed input to semi-intensive shrimp grow out ponds. J. World Aquacult. Soc. 23 (1) 23-30. 
GERENTE C, PIERRE COUESPEL DU MESNIL, YVES ANDRES, JEAN-FRANCOIS THIBAULT and PIERRE LE CLOIREC (2000) Removal of metal ions from aqueous solution on low cost natural polysaccharides Sorption mechanism approach. React. Funct. Polym. 46 135-144.

JIANLONG WANG, XINMIN ZHAN and YI QUAN (2000) Removal of $\mathrm{Cr}(\mathrm{VI})$ from aqueous solution by macroporous resin adsorption. J. Environ. Sci. Health A35 (7) 1211-1230.

KRISHNANI KK, AZAD IS, KAILASAM M, THIRUNAVUKKARASU AR, GUPTA BP, JOSEPH KO, MURALIDHAR M and ABRAHAM M (2003) Acute toxicity of some heavy metals to Lates calcarifer fry with a note on its histopathological manifestations. J. Environ. Sci. Health 38 (4) 645-655.

NKHALAMBAYAUSI-CHIRWA EM and WANG YT (2001) Simultaneous chromium(VI) reduction and phenol degradation in a fixed film coculture bioreactor: Reactor performance. Water Res. 35 1921-1932.

OLIVER DS, BROCKMAN FJ, BOWMAN RS and KIEFT TL (2003) Microbial reduction of hexavalent chromium under vadose zone conditions. J. Environ. Qual. 32 (1) 317-324.

RAJI C and ANIRUDHAN TS (1998) Batch Cr (VI) removal by polyacrylamide-grafted saw dust: Kinetics and thermodynamics Water Res. 32 (12) 3772-3780.

REDDAD Z, ZERENTE C, ANDRES Y and CLOIREC P LE (2003) Mechanisms of $\mathrm{Cr}(\mathrm{III})$ and $\mathrm{Cr}(\mathrm{VI})$ removal from aqueous solutions by sugar beet pulp. Environ. Toxicol. 24 257-264.

REDDAD Z, ZERENTE C, ANDRES Y and CLOIREC P LE (2002) Adsorption of several metal ions onto a low cost biosorbent: Kinetic and Equilibrium studies. Environ. Sci. Technol. 36 20672073.

STANDARD METHODS (1989) Standard Methods for the Examination of Water and Waste Water. American Public Health Association (APHA, AWWA, WEF) Washington DC.

STRICKLAND JDH and PARSONS TRA (1972) In: Stevenson JC (ed.) Practical Handbook of Seawater Analysis ( $2^{\text {nd }}$ edn.) Bulletin 167 Research Board of Canada, Ottawa, Canada.

VIARENGO A (1989) Heavy metals in marine vertebrates: Mechanism of regulation and toxicity at the cellular level. Rev. Aquat. Sci. 1295.

WIELINGA B, MIZUBA MM, HANSEL CM and FENDORF S (2001) Iron promoted reduction of chromate by dissimilatory iron reducing bacteria. Environ. Sci. Technol. 35 522-527. 
